\title{
Shu-mei Shih, Visuality and Identity. Sinophone Articulations across the Pacific
}

\section{Emmanuel Lincot}

\section{Q OpenEdition}

\section{Journals}

Édition électronique

URL : http://journals.openedition.org/chinaperspectives/2713

DOI : 10.4000/chinaperspectives. 2713

ISSN : 1996-4617

Éditeur

Centre d'étude français sur la Chine contemporaine

\section{Édition imprimée}

Date de publication : 15 décembre 2007

ISSN : 2070-3449

Référence électronique

Emmanuel Lincot, "Shu-mei Shih, Visuality and Identity. Sinophone Articulations across the Pacific », China Perspectives [En ligne], 2007/4 | 2007, mis en ligne le 09 avril 2008, consulté le 21 septembre 2020. URL : http://journals.openedition.org/chinaperspectives/2713 ; DOI : https://doi.org/10.4000/ chinaperspectives. 2713

Ce document a été généré automatiquement le 21 septembre 2020.

(C) All rights reserved 


\title{
Shu-mei Shih, Visuality and Identity. Sinophone Articulations across the Pacific
}

\author{
Emmanuel Lincot
}

1 A Professor of comparative literature at the University of California, Los Angeles (UCLA), and a specialist in gender studies, Shu-mei Shih, in this new book, adopts an original approach to the question of identity in today's Sinophone world. At 244 pages in length, Visuality and Identity. Sinophone Articulations across the Pacific comprises an introduction and six parts: the first deals with globalisation and its effects on minorities, and the second with the more specific case of transnational feminism in the Sinophone milieu, which opens up a more general discussion on the relationship to cosmopolitism and to the idea of empire, which is treated in the remaining parts. More fundamentally, Shih's thesis is to demonstrate that the Chinese communities situated on both shores of the Pacific adhere more to linguistic and emotional values mediated through a global and visual culture than to ethnic or national references.

2 The idea is seductive and starts out from an established finding: the Sinophone world is a plural one whose cultural and economic enrichment is developing in a complex network that remains, on the surface, outside the realm of sovereignty of any state. To back up her argument, Shi draws inspiration from the theories of Gilles Deleuze (that of the rhizome in particular) and of Paul Virilio (relating to the ubiquity of urban cultural phenomena), but also from the works of Françoise Lionnet on the Francophone world, and of Fredric Jameson, who posits that experience, since the middle of the 20 th century, is passed on through images. Elsewhere, Shih makes recourse to visual sources (contemporary art, television productions, the Internet), a commendable initiative given the fact, underlined by the author, that "Many contemporary Western thinkers share the suspicion of the visual and take different notions from poststructuralism to

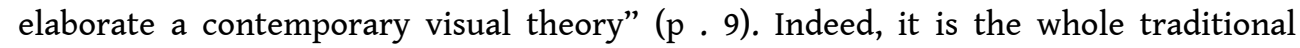
pattern of the relationship to culture that finds itself overwhelmed by the media. The great merit of this work is to show that the new networks of culture that irrigate the 
Sinophone world are not simple distribution channels. They are made up of interactive mechanisms where the hierarchical relations between transmitters and receivers, and with them the relations between distributors and consumers, are becoming blurred. From this confusion is born a deterritorialized citizenship (p. 43), the emblematic names of which include the film directors Ang Lee and John Woo but also the visual artists Hung Liu and Wu Mali , some of whose works are reproduced in the book. These new cultural geopolitics have changed our perception of the Chinese world and its frontiers and with it what the sociologist of everyday life Erving Goffman, whom the author curiously fails to quote, refers to as the "interaction ritual".

It is, however, to this analysis that Shu-mei Shih devotes chapter III, which, under the lovely title The Geopolitics of Desire, deals with the passions that, in reality or fictitiously, play off against each other the wives of Taiwanese businessmen and their mainland rivals; genuine power struggles that reveal - well beyond the political antagonisms characteristic of the Taiwan Strait - powerful and ambiguous conflicts of identity, sometimes stamped by mixed feelings, sisterly or maternal, of love and hate. However, one question left unsettled by the author excites the curiosity of the reader: who are the players in the Sinophone world of which Shih speaks? They constitute, in essence, an elite of the artists, businesspeople, and/or committed feminists who form a "bridge" between the Chinese mainland, Hong Kong, Taiwan, and the megalopolises of California . The circulation of this elite, if one follows the theoretical model set out not too long ago by the sociologist Vilfredo Pareto, is probably not unrelated to the sociopolitical stability of China on the one hand and, on the other, the definition of a policy that the Beijing authorities notably qualify today as China 's soft power (ruan shili). Even if this economic and cultural influence is quite removed from the concept originally forged by the American political scientist Joseph Nye, it remains no less significant that Beijing has undertaken since 2004 to set up a network of Confucius Institutes throughout the world, cultural and language centres built on the model of the Alliance Française or the Goethe Institute.

4 As a consequence, two observations can be made. First, if the style of the programmes distributed by the Chinese media sometimes panders exclusively to a popular craze for kung-fu stories with anachronistic tonalities (p. 2) - comparable in this respect to the fiction of Jin Yong, for example - these same broadcasts attempt to transmit and systematically establish the signs of a cultural and language identification through the use of Mandarin among actors as different as Michelle Yeoh in Malaysia or Chow Yunfat in Hong Kong . Beyond these signs one may distinguish an imperial attempt for control sometimes emanating from a regalian power that has renounced none of its prerogatives, censorship in particular, as Frédéric Douzet has demonstrated in his recent studies on nation states and the governance of the Internet. Secondly, the Sinophone world of the image has not dissolved in a transnational lingua franca dominated by the West under the influence of capitalism and globalisation. The frontiers of this Sinophone world are shifting, and along these frontiers the logic of the state sometimes comes into conflict with the logic of the individual, even if the two sometimes overlap, redefining new forms of belonging in terms of identity and memory as defined by Maurice Halbwachs. These sociological, ethical, and political aspects could perhaps have been studied more thoroughly by the author. Similarly, a comparative parallel between the problematics put forward by Shih and works as important as those developed (albeit in different historical and geographical contexts) by Michel Maffesoli, Joël Thoraval, Pierre Barboza, or Craig Peariso - whether they 
concern the transfiguration of politics and the tribalisation of social systems or the anthropological changes in identity in the Chinese world, or even the circulation of images and the question of deviance in the relationship with the media - would have given greater depth to this general reflection. Subject to the reservation of these last observations, the work of Shu-mei Shih is innovative in its subject matter and will assuredly lead to many more explorations

Translated by Nick Oates 